UDC 636.2.03

\title{
EFFECT OF SEX AND AGE ON BEEF CATTLE MEAT pH
}

\author{
I. Muižniece*, D. Kairiša \\ Latvia University of Life Science and Technologies, Faculty of Agriculture, \\ Institute of Animal Science, Liela street 2, LV-3001, Jelgava, Latvia \\ E: muiznieceinga@inbox.lv
}

Received May 12, 2020 / Received June 18, 2020 / Accepted July 20, 2020

\begin{abstract}
Aim. The aim of the study was to explain the difference of $\mathrm{pH}$ values in heifer and bull meat and to carry out an analysis of the effect of age in groups of both sexes. Methods. The study contains data on 2,469 beef breed and their crossbreed cattle fattened on farms in Latvia and Lithuania, slaughtered in a certified Lithuanian slaughterhouse 'Agaras' in 2018. For the assessment of the effect of sex, the beef cattle were divided into 2 study groups: 1,266 bulls and 1,203 heifers. 3 study groups were created for analysis of the effect of age: $12-$ 17 months; $18-23$ months; 24 and more months. Analysis of the data acquired was based on the indicators of descriptive statistics. T-test and Pearson correlation analysis were used. Results. The average $\mathrm{pH}$ in the meat of bulls was $5.87 \pm 0.011$, but in the meat obtained from heifers $-5.66 \pm 0.005(p \leqslant 0.05)$. Within the desired $\mathrm{pH}$ value from 5.4 to 5.8 , the group of bulls comprised $65 \%$ of carcasses and the group of heifers $-86 \%$ of carcasses. In the group of bulls, $35 \%$ of carcasses had an increased $\mathrm{pH}$ in the meat $(\mathrm{pH}-\geqslant 5.9)$, while in the heifers' group $-13 \%$. For a small part of the carcasses in both study groups, too low $\mathrm{pH}$ was found in meat $(\mathrm{pH} \leqslant 5.3)$, with $1 \%$ in the group of bulls and $0.4 \%$ in the group of heifers. An analysis of the effect of age found no significant differences in $\mathrm{pH}$ values between bulls of different ages. In the heifers'study group, the highest $\mathrm{pH}$ in meat was found in the group above 24 months of age, $\mathrm{pH}-5.69$. Correlation analysis between the meat $\mathrm{pH}$ and the slaughter results showed a weak or non-existent relationship. In the overall study group, stronger correlation was observed between $\mathrm{pH}$ and fat score $(r=-0.21, p<0.05)$. Conclusions. The results indicate that meat from heifers is better quality in terms of desired $\mathrm{pH}$. Meat with the desired $\mathrm{pH}$ can be used in the production of high-quality products that provide higher profits.
\end{abstract}

Key words: beef cattle, meat, $\mathrm{pH}$, age, sex.

DOI:

\section{INTRODUCTION}

One of the main characteristics of beef meat quality is the $\mathrm{pH}$ value, which is closely related to the obtainment of quality meat. $\mathrm{pH}$ in beef carcasses is measured 12 to $48 \mathrm{~h}$ after slaughter, and the desired $\mathrm{pH}$ in meat should be between 5.4 and 5.8. Such meat can be maturated in a quality manner, which ensures high demands and exceptional eating experience as well as maturing provides the palatability and increases the tenderness. Meat with the desirable $\mathrm{pH}$ could be sold fresh or packaged in a vacuum, and stored, it is visually appealing to the consumer, with good flavor characteristics (Adzitey F, Huda N 2011; Velotto S et al. 2015).

When the animal is alive, energy in muscles is stored in the form of glycogen, and $\mathrm{pH}$ in muscles is $>7.1$.

I. MUIŽNIECE, D. KAIRIŠA, 2020
After death has occurred, glycolysis in muscles takes place, in the result of which glycogen is split to lactic acid and other metabolites, which contributes to falling of $\mathrm{pH}$. The larger energy reserves in muscles, the greater amounts of lactic acid will be produced. As a result of various stress factors, glycogen reserves are already spent before slaughter and thus a normal process of glycolysis cannot occur after slaughter.

The extent of loss of glycogen will depend on the intensity and duration of the various stress factors and on the sensitivity of animals to stress. If the animal is subjected to long-term stress prior to slaughter, e.g. long-term transportation, starvation, too high density in stocking conditions (Arik E, Karaca S 2017; Ferguson DM et al. 2001; Ferguson DM, Gerrard DE 2014), the reserves of muscle glycogen are dwindling and, following the slaughter of the animal, the acidification of 
the meat, or a decrease in $\mathrm{pH}$ value to the desired limit, does not occur or does not occur sufficiently. This results in DFD (Dark, Firm, and Dry) meat having an increased $\mathrm{pH}$ of a value of $\geq 5$.9. It is characterized by a dark color, increased water binding and toughness (especially if $\mathrm{pH}$ is between 5.9 and 6.2). A DFD meat is subjected to the risk of faster deterioration as a result of the effects of microorganisms on its surface (Page JK et al. 2001; Pipek P et al. 2003; Villarroel M et al. 2003). A study by Villarroel M et al. (2003) found that meat with a $\mathrm{pH}$ of $>5.55$ is already getting tougher, has a less pronounced taste and is visually appealing to a lesser extent.

Meat with a too low $\mathrm{pH}(\leq 5.3)$ is referred to as PSE (Pale, Soft and Exudative) meat and is pale, watery and too soft. In the case of PSE meat, a decrease in $\mathrm{pH}$ is taking place while the carcass is still warm, with a decrease below 6.0 occurring already 45 minutes after the slaughter (Adzitey F, Huda N 2011).

Meat obtains the characteristics of PSE if the animal is subjected to severe, temporary stress shortly before slaughter, and therefore depends on the quality of the work at the slaughterhouse. A PSE meat will be obtained by the use of electric whips for the moving the animals to the slaughter spot, beating of animals, an incorrect grouping of animals, and excessive density in the pre-slaughter waiting room, as well as poor-quality slaughter.

Cattle breed has influence on several slaughter result parameters, such as live weight before slaughter, live weight gain, slaughter weight, dressing percentage and conformation score (Muizniece I, Kairisa D 2016), but as shown in other studies, breed has not significant influence on $\mathrm{pH}$ value of beef meat (Arik E, Karaca $\mathrm{S}$ 2017; Bures D et al. 2006; Cafferkey J et al. 2019).

An important factor influencing the quality of the meat obtained is the sex of the animal, which affects not only the chemical composition of the meat but also physicochemical and sensory properties (Page JK et al. 2001; Weglarz A 2010b; Weglarz A 2011). Heifers and steers produce more marbled, gentler meat with better sensing properties compared to the meat obtained from bulls. The bull meat is darker, with more coarse muscle fibres and a higher $\mathrm{pH}$, which makes it less suitable for fresh sale (Marencic D et al. 2018; Weglarz A 2010b).

The aim of the study was to explain the difference of $\mathrm{pH}$ values of heifers and bull's meat and to carry out an analysis of the effect of age in groups of both sexes of beef cattle.

\section{MATERIALS AND METHODS}

The study used $\mathrm{pH}$ measurements of meat of 2,469 beef purebred (Charolais, Limousin, Angus, Hereford, Aubrac, Simmental) and their crossbreed cattle fattened on farms in Latvia and Lithuania, slaughtered in a certified Lithuanian slaughterhouse 'Agaras' in 2018. $\mathrm{pH}$ measurements in the meat were carried out 24 hours after the slaughter of beef cattle in the loin section, using a $\mathrm{pH}$ meter ProfiLine $\mathrm{pH} 3310$. In our study, it was assumed that an increased $\mathrm{pH}$ starts at a value of 5.90 but $\mathrm{pH} 5.30$ and lower is considered to be too low. It was adopted on the basis of guidelines developed by the slaughterhouse 'Agaras'.

Cattle used in the study were between 12 and 45 months old.

For the assessment of the effect of sex, the beef cattle were divided into 2 study groups:

1. bulls $(n=1,266)$

2 . heifers $(n=1,203)$.

According to the following scheme, 3 study groups were set up for analysis of the effect of age (Table 1). Most of heifers were slaughtered between the age of 18 and 24 months, $51.7 \%$, while in the bull group most of the bulls were slaughtered between 12 and 17 months, 56.2\%.

In the age group over 24 months, 40 bulls (3.1\%) and 263 heifers $(21.9 \%)$ were slaughtered.

The indicators used in the study: sex, age, live weight, slaughter weight, conformation score, fat score and meat $\mathrm{pH}$, were obtained from the slaughterhouse 'Agaras' protocols.

For the calculation of dressing percentage, used was the following formula (1):

$$
K=\frac{W k}{W t} \times 100
$$

where $\mathrm{K}$ - dressing percentage, $\%$; Wk - cold carcass weight, kg; Wt - live weight before slaughter, kg.

For the conformation score grading, EUROP (carcass classification system) letters are used, marked with the following meaning: $\mathrm{E}$ - excellent (numerical mark 5), U - very good (4), R - good (3), O - moderate (2), $\mathrm{P}-$ weak (1). The evaluation of fat score is indicated by figures 1 to 5 , where 1 - very low, 2 - low, 3 - moderate, 4 - high, 5 - very high. Carcasses classification was done by slaughterhouse 'Agaras' expert according with Regulation (EU) No 1308/2013.

Analysis of the data acquired was based on the indicators of descriptive statistics: arithmetical mean, 
standard error and coefficient of variation. $T$-test for average values was used for significance determination for trait relationship. Pearson correlation analysis was performed, which was established between the $\mathrm{pH}$ and and the features of slaughter. Different letters $(a, b, c)$ on tables mark significant differences at $p \leq 0.05$.

\section{RESULTS AND DISCUSSION}

The results of the study are summarized in Table 2 . The average age of bulls prior to slaughter was 17.3 months, and 20.4 months in the heifers' group ( $p \leq$ $0.05)$. Before slaughter, the bulls showed a higher live weight and slaughter weight of $529.6 \pm 1.68 \mathrm{~kg}$ and $294.0 \pm 1.13 \mathrm{~kg}$, respectively; in the heifers' group, the respective indicators were $498.7 \pm 1.53 \mathrm{~kg}$ and 269.8 $\pm 0.97 \mathrm{~kg}(p \leq 0.05)$. Calculated dressing percentage was also higher in the bulls' group, in average - 55.5 $\pm 0.10 \%$, while in the heifers' group $-54.1 \pm 0.12 \%$ $(p \leq 0.05)$. Similar results have been found in studies by other authors (Blanco M et al. 2020; Bures D, Barton L 2012; Pesonen M, Huuskonen A 2015; Weglarz A 2010a;) showing that bulls before slaughter reached higher weight and dressing percentage.

The highest conformation score was obtained from bulls' group $-3.01 \pm 0.02$ points and it was significantly higher than heifers' group carcass conformation score $(\mathrm{p} \leqslant 0.05)$. Heifers' group received significantly higher fat score $-2.98 \pm 0.01$. As shown by the work of several other researchers, bulls are characterized by better muscularity, while heifers show a higher fat content on carcass (Blanco M et al. 2020; PogorzelskaPrzybyłek et al. 2018).

After the carcasses were refrigerated, the average $\mathrm{pH}$ in the meat of bulls was $5.87 \pm 0.011$, while in the meat of heifers, the $\mathrm{pH}$ was $5.66 \pm 0.005$, a difference of 0.22 , which is significant $(p \leq 0.05)$. Also, several studies conducted by foreign scientists, like our study, found that $\mathrm{pH}$ was higher in bull meat rather than in that of heifers and that the difference was significant (Page JK et al. 2001; Weglarz A 2010a; Weglarz A 2010b; Weglarz A 2011; Zhang YY et al. 2010). The results obtained show that heifers are more stress-resistant and suffer from stressors that occur during transportation and during the pre-slaughter stocking to a lesser extent. Bulls are more sensitive to various changes and more under the influence of hormonal functioning aimed at fighting and proof of dominance, thus being in a continuous state of anxiety which, in its turn, has a negative effect on the quality of their meat.

Both study groups contained carcasses in the meat of which $\mathrm{pH}$ exceeded the desired limit - 5.90. In the group of bulls, $35 \%$ of carcasses were with an increased $\mathrm{pH}$ in the meat, while in the heifers' group $-13 \%$. Within the desired span of the $\mathrm{pH}$ of a value of 5.40 to 5.80, the percentage of carcasses reached $65 \%$ in the group of bulls, and $86 \%$ - in the group of heifers (Figure). For a small part of the carcasses in both study groups, too low $\mathrm{pH}$ was found in meat $(\mathrm{pH} \leq 5.3)$, with $1 \%$ in the group of bulls and $0.4 \%$ in the group of heifers.

Several studies have shown that it is also possible to obtain meat from bulls with a $\mathrm{pH}$ value not exceeding 5.8 (Cafferkey J et al. 2019; Moran L et al. 2019;

Table 1. Number of animals used in the study groups of sex and age

\begin{tabular}{c|c|c|c}
\hline \multirow{2}{*}{ Sex } & \multicolumn{3}{|c}{ Age (months) } \\
\cline { 2 - 4 } & $12-17$ & $18-23$ & 24 and more \\
\hline Heifers & 318 & 622 & 263 \\
Bulls & 711 & 515 & 40 \\
\hline
\end{tabular}

Table 2. Results of slaughter and carcass quality in study groups

\begin{tabular}{l|c|c|c|c}
\hline \multirow{2}{*}{\multicolumn{1}{c|}{ Indicators }} & \multicolumn{2}{c|}{ Bulls $(n=1266)$} & \multicolumn{2}{c}{ Heifers $(n=1203)$} \\
\cline { 2 - 5 } & $x \pm S x$ & $v, \%$ & $x \pm S x$ & $v, \%$ \\
\hline Age before slaughter (months) & $17.3 \pm 0.09^{\mathrm{a}}$ & 19.39 & $20.4 \pm 0.12^{\mathrm{b}}$ & 19.72 \\
Live weight before slaughter & $529.6 \pm 1.68$ & 11.31 & $498.7 \pm 1.53$ & 10.65 \\
$(\mathrm{~kg})$ & $294.0 \pm 1.13^{\mathrm{a}}$ & 13.65 & $269.8 \pm 0.97^{\mathrm{b}}$ & 12.49 \\
Cold carcass weight (kg) & $55.5 \pm 0.10^{\mathrm{a}}$ & 6.37 & $54.1 \pm 0.12^{\mathrm{b}}$ & 7.40 \\
Dressing percentage (\%) & $3.01 \pm 0.02^{\mathrm{a}}$ & 20.55 & $2.86 \pm 0.02^{\mathrm{b}}$ & 16.77 \\
Conformation score (points) & $2.24 \pm 0.01^{\mathrm{a}}$ & 20.11 & $2.98 \pm 0.01^{\mathrm{b}}$ & 18.26 \\
Fat score (points) & $5.87 \pm 0.011^{\mathrm{a}}$ & 6.77 & $5.66 \pm 0.005^{\mathrm{b}}$ & 3.03 \\
$\mathrm{pH}$ & & & & \\
\hline
\end{tabular}

Note. $\mathrm{a} b-$ significant differences between the study groups, $\mathrm{p} \leq 0.05$. 
MUIŽNIECE et al.

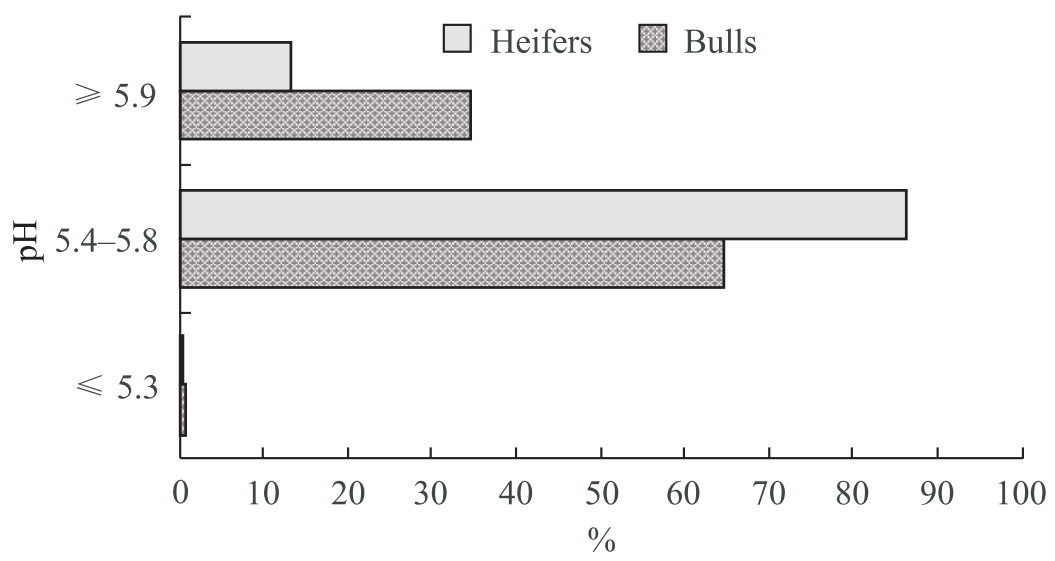

The percentage of $\mathrm{pH}$ in bull and heifer meat

Soidla $\mathrm{R}$ et al. 2019). These studies were conducted on a relatively small number of animals, mainly on study farms, where stress factors could be minimized both on the farm, during transportation and before slaughter.

Upon the conduct of the analysis of the effect of age on changes in $\mathrm{pH}$ according to the group of sex, it was found that in the bulls' group $\mathrm{pH}$ in meat did not differ significantly in different ages (Table 3). The average $\mathrm{pH}$ of the meat was between 5.85 and 5.88.

The $\mathrm{pH}$ of the meat obtained from heifers ranged from 5.63 to 5.69. The highest $\mathrm{pH}$ in meat was found in the group above 24 months of age -5.69 , which was by 0.03 higher than in the age group of 18 to 23 months and by 0.06 higher than in the age group 12 17 months $(p \leq 0.05)$. A study conducted by Weglarz A (2010) showed that beef from cows slaughtered during the winter and summer season was higher than that of heifers $(>5.8)$. In heifer meat, $\mathrm{pH}<5.8$ was present in $72.5 \%$ of cases in the winter season and over $86 \%$ in the summer season. The percentage of cow meat at the desired $\mathrm{pH}$ value was only $46.75 \%$ during the winter season, but only slightly above $30 \%$ of carcasses met the desired value of $\mathrm{pH}$ during the summer season. The results have shown that, as the age of female beef cattle increases, they respond to

Table 3. $\mathrm{pH}$ value indicators in beef cattle meat in study groups of different age and sex

\begin{tabular}{l|c|c|c|c}
\hline \multirow{2}{*}{ Age group } & \multicolumn{2}{|c|}{ Bulls } & \multicolumn{2}{c}{ Heifers } \\
\cline { 2 - 5 } & $x \pm S x$ & $v, \%$ & $x \pm S x$ & $v, \%$ \\
\hline $12-17$ months & $5.88 \pm 0.02$ & 6.87 & $5.63 \pm 0.01^{\mathrm{a}}$ & 2.93 \\
$18-23$ months & $5.85 \pm 0.02$ & 6.68 & $5.66 \pm 0.01^{\mathrm{b}}$ & 2.83 \\
$>24$ months & $5.87 \pm 0.06$ & 6.13 & $5.69 \pm 0.01^{\mathrm{c}}$ & 3.47 \\
\hline
\end{tabular}

Note. a b c - significant differences between the study groups, $\mathrm{p} \leq 0.05$.

Table 4. Pearson correlation coefficients between the features of $\mathrm{pH}$ and of slaughter results

\begin{tabular}{l|c|c|c|c|c|c}
\hline \multicolumn{1}{c|}{ Group } & Age & $\begin{array}{c}\text { Live } \\
\text { weight }\end{array}$ & $\begin{array}{c}\text { Slaughter } \\
\text { weight }\end{array}$ & $\begin{array}{c}\text { Dressing } \\
\text { percentage }\end{array}$ & $\begin{array}{c}\text { Conformation } \\
\text { score }\end{array}$ & Fat \\
\hline \multicolumn{7}{|c}{$p H$} \\
\hline Total $(n=2469)$ & -0.10 & 0.06 & 0.06 & 0.02 & -0.05 & $-0.21 *$ \\
bulls & -0.02 & -0.02 & -0.04 & -0.05 & $-0.09 *$ & -0.0004 \\
heifers & $0.13 *$ & -0.05 & -0.06 & -0.04 & $-0.10 *$ & $-0.08 *$ \\
\hline
\end{tabular}

Note. $\mathrm{p} \leq 0.05$. 
different changes more sensitively and suffer more from the effects of stress.

An analysis of the correlation between the features of $\mathrm{pH}$ and of slaughter results showed weak or non-existent relationships (Table 4). In the overall study group, a closer correlation was observed between the features of $\mathrm{pH}$ and of fat score, nevertheless, it was weak $(-0.21)$, but significant $(p<0.05)$.

A study by Weglarz A (2010a) shows similar Pearson correlation results between the features of $\mathrm{pH}$ and of slaughter results - the correlations obtained were weak or did not exist. A study conducted by Mach N et al (2008) results showed that fat score had a significant relationship with $\mathrm{pH}$ - the higher the fat score value, the smaller the number of cases with increased $\mathrm{pH}$ was identified. Conformation score was also in correlation with $\mathrm{pH}$ - the lower the conformation score, the higher the growth of the number of cases with increased $\mathrm{pH}$.

\section{CONCLUSIONS}

The biggest weight before slaughter, slaughter weight and dressing percentage showed bulls' group, but heifers' group obtained highest fat score.

In the group of bulls, the average $\mathrm{pH}$ value was 5.87, while in the group of heifers it was $5.66(p \leq 0.05)$. $35 \%$ of the carcasses of bulls had an increased $\mathrm{pH}$ of $\geq 5.90$, but in the heifers' group, an increased $\mathrm{pH}$ has been identified in only $13 \%$ of the carcasses. An increased $\mathrm{pH}$ means that these carcasses will only be used for the production of processed products, thus the creation of lower-value products.

Based on the analysis of the effect of age, we can conclude that the age of the bulls did not have a significant effect on the $\mathrm{pH}$ value, but the findings in the group of heifers show that $\mathrm{pH}$ increased with the age, while remained within the required limits for the obtainment of quality meat.

Adherence to ethical principles. All the European Union and national principles of caring for animals and using them have been complied with.

Conflict of interests. The authors declare that they have no conflict of interests.

Financing. This study was not financed by any grants from financing institutions in the state, commercial or non-commercial sectors. This work has been supported by the project of 'University of Life Sciences and Technologies' No 3.2.-8/57 'Beef cattle and their crossbreed suitability for fattening with grass forage'.

\section{Вплив статі та віку на рН яловичини}

Muižniece I.*, Kairiša D.

Latvia University of Life Science and Technologies, Faculty of Agriculture, Institute of Animal Science,

Liela street 2, LV-3001. Jelgava, Latvia

e-mail: muiznieceinga@inbox.lv

Мета. Метою дослідження було пояснити різницю між значеннями $\mathrm{pH}$ яловичини від телиць та бичків $\mathrm{i}$ провести аналіз впливу віку у групах тварин обох статей. Методи. Дослідження містить дані щодо 2469 представників порід великої рогатої худоби та їхніх гібридів, яких відгодовували у господарствах Латвії та Литви і забивали на сертифікованій бійні «Agaras», Литва, у 2018 р. 3 метою оцінки впливу статі велику рогату худобу поділили на дві групи дослідження: 1266 бичків та 1203 телиць. Для аналізу впливу віку було створено три групи дослідження: 12-17 місяців; 18-23 місяців; 24 і більше місяців. Аналіз отриманих даних грунтувався на показниках описової статистики. Були використані t-критерій Стьюдента та коефіцієнт кореляції Пірсона. Результати. Середнє значення $\mathrm{pH}$ м'яса бичків становило $5,87 \pm 0,011$, а м'яса, отриманого від телиць, $-5,66 \pm 0,005(p \leqslant 0,05)$. У межах бажаних значень $\mathrm{pH}$ від 5,4 до 5,8, група бичків складала $65 \%$ туш, а група телиць - $86 \%$ туш. У групі бичків, $35 \%$ туш мали підвищене значення $\mathrm{pH}$ м'яса ( $\mathrm{pH}-\geq 5,9)$, у той час як у групі телиць - $13 \%$. У невеликій частині туш $з$ обох груп дослідження було виявлено занадто низьке значення $\mathrm{pH}$ м'яса $(\mathrm{pH} \leq 5,3)-1 \%$ у групі бичків і $0,4 \%$ у групі телиць. Аналіз впливу віку не виявив значних відмінностей між значеннями $\mathrm{pH}$ щодо бичків різного віку. Що стосується групи телиць, найвище значення $\mathrm{pH}$ м'яса було виявлено у групі віком понад 24 місяці, $\mathrm{pH}-5,69$. Аналіз кореляції між значеннями $\mathrm{pH}$ м'яса та результатами забою продемонстрував слабкий або відсутній зв'язок. Загалом у групі дослідження було помічено сильніший зв'язок між показниками $\mathrm{pH}$ та жирності $(r=-0,21, p<0,05)$. Висновки. Результати вказують на те, що м’ясо телиць має кращу якість у плані бажаних значень $\mathrm{pH}$. М'ясо з бажаними показниками $\mathrm{pH}$ можна використовувати у виробництві високоякісної продукції, що забезпечить більший прибуток.

Ключові слова: велика рогата худоба, м’ясо, $\mathrm{pH}$, вік, стать.

\section{REFERENCES}

Adzitey F, Huda N. (2011) Pale soft exudative (PSE) and dark firm dry (DFD) meats: Causes and measures to reduce these incidences $-A$ mini review. Inter. Food Res. J. 18(1):11-20.

Arik E, Karaca S. (2017) The effect of some pre-slaughter 
factors on meat quality of bulls slaughtered in a commercial abattoir in Turkey. Indian J. Anim. Res. 51(3):557-63. doi: 10.18805/ijar.v0iOF.4563.

Blanco M, Ripoll G, Delavaud C, Casasús I. (2020) Performance, carcass and meat quality of young bulls, steers and heifers slaughtered at a common body weight. Livestock Sci. 240:1-9. doi.org/10.1016/j.livsci.2020. 104156.

Bures D, Barton L, Teslik V, Zahradkova R. (2006) Meat quality characteristics of beef from Charolais and Simmental bulls fed different diets. $57^{\text {th }}$ Annual Meeting of the European Association for Animal Production (EAAP), Turkey, Antalya, 17-20 September 2006, 1-4.

Bures D, Barton L. (2012) Growth performance, carcass traits and meat quality of bulls and heifers slaughtered at different ages. Czech. J. Anim. Sci. 57(1):34-43. doi: 10.17221/5482-CJAS.

Cafferky J, Hamill RM, Allen P, O’Doherty JV, Cromie A, Sweeney T (2019) Effect of breed and gender on meat quality of M. longissimus thoracis et lumborum muscle from crossbred beef bulls and steers. Foods 8(173):1-10. doi.org/10.3390/foods 8050173

Ferguson DM, Bruce HL, Thompson JM, Egan AF, Perry $D$, Shorthose WR. (2001). Factors affecting beef palatability-farmgate to chilled carcass. Austral. J. Exper. Agric. 41(7):879-91. doi: 10.1071/EA00022.

Ferguson DM., Gerrard DE. (2014) Regulation of postmortem glycolysis in ruminant muscle. Anim. Prod. Sci. 54(4):464-81. https://doi.org/10.1071/AN13088.

Mach N, Bach A, Velarde A, Devant M. (2008) Association between animal, transportation, slaughterhouse practices, and meat $\mathrm{pH}$ in beef. Meat Sci. 78(3):232-8. doi: 10.1016/j.meatsci.2007.06.021.

Marencic D, Ivankovic A, Kozacinski L, Popovic M, Cvrtila $Z$. (2018). The effect of sex and age at slaughter on the physicochemical properties of baby-beef meat. Veterinarski Arhiv. 88(1):101-10. doi: 10.24099/vet. arhiv. 160720.

Moran L, Wilson SS, McElhinney CK, Monahan FJ, McGee M, O'Sullivan MG, O'Riordan EG, Kerry JP, Moloney $A P$. (2019) Suckler bulls slaughtered at 15 months of age: Effect of different production systems on the fatty acid profile and selected quality characteristics of Longissimus thoracis. Foods 8(7):264. doi.org/10.3390/ foods 8070264 .

Mueller LF, Balieiro JCC, Ferrinho AM, Martins T da S, da Silva Corte RRP, de Amorim TR, de Jesus Mangini Furlan J, Baldi F, Pereira ASC. (2019) Gender status effect on carcass and meat quality traits of feedlot Angus $\times$ Nellore cattle. Anim. Sci. J. 90(8):1078-89. https://doi. org/10.1111/asj.13250.

Muizniece I, Kairisa D. (2016) Different beef breed cattle fattening results analysis. Proc. Res. Rural Develop. 1:57-62.

Page JK, Wulf DM, Schwotzer TR. (2001) A survey of beef muscle colour and pH. J. Anim. Sci. 79(3):678-87. doi: 10.2527/2001.793678x.

Pesonen M, Huuskonen A. (2015) Production, carcass characteristics and valuable cuts of beef breed bulls and heifers in Finnish beef cattle population. Agric. Food Sci. 24(3):164-72. doi: 10.23986/afsci.50930.

Pipek P, Haberl A, Jelenikova J. (2003) Influence of slaughterhouse handling on the quality of beef carcasses. Czech J. Anim. Sci. 39:371-8.

Pogorzelska-Przybytek P, Nogalski Z, Sobczuk-Szul M, Purwin C, Kubiak D. (2018) Carcass characteristics and meat quality of Holstein-Friesian $\times$ Hereford cattle of different sex categories and slaughter ages. Arch. Anim. Breed. 61(2):253-61. https://doi.org/10.5194/aab-61-2532018.

Soidla R. Kerner K. Tepper M. Tanavots A. Kaart T, Jou$d u$ I. (2019) The effect of ageing on chosen quality characteristics of skeletal muscles of Aberdeen Angus bulls. Agronom. Res. 17(2):1472-84. doi: 10.15159/AR. 19.069 .

Velotto S, Pagano F, Barone CMA, Esposito M, Civale G, Crasto A. (2015) Effect of aging technologies on some qualitative characteristics of Longissimus dorsi muscle of Marchigiana beef. Agronom. Res. 13(4):1143-51.

Villarroel M., Maria GA, Sanudo C, Olleta JL, Gebresenbet G. (2003) Effect of transport time on sensorial aspects of beef meat quality. Meat Sci. 63(3):353-7. doi.org/ 10.1016/S0309-1740(02)00093-1.

Weglarz A. (2010a) Meat quality defined based on $\mathrm{pH}$ and colour depending on cattle category and slaughter season. Czech. J. Anim. Sci. 55(12):548-56. doi: 10.17221/2520CJAS.

Weglarz A. (2010b) Quality of beef from semi-intensively fattened heifers and bulls. Anim. Sci. Paper. Rep. 28 (3):207-18.

Weglarz A. (2011) Effect of pre-slaughter housing of different cattle categories on beef quality. Anim. Sci. Paper. Rep. 29(1):43-52.

Zhang $Y$-Y, Zan $L-S$, Wang $H-B$, Xin YPCM, Adoligbe $C M$, Ujan JA. (2010) Effect of sex on meat quality characteristics of Qinchuan cattle. Afr. J. Biotechnol. 9(28): 4504-9. 


\section{ПРАВИЛА ДЛЯ АВТОРІВ}

У журналі «Agricultural Science and Practice» публікуються результати фундаментальних досліджень 3 питань агрономії, біології, біотехнології та біоінженерії, ветеринарної медицини.

Друкуються фундаментальні статті, огляди літератури, короткі повідомлення, які раніше не видавалися. Особливо просимо уникати технічного плагіату та самоплагіату. Редакція дуже уважно відслідковує ці моменти.

Рукописи надсилаються на конфіденційне рецензування спеціалістам відповідної галузі.

За умови позитивної рецензії з рукописом знайомиться науковий редактор - конфіденційно.

Статті надсилаються українською/російською мовою, перекладаються в редакції безкоштовно і публікуються лише англійською мовою; резюме - українською мовою. В електронній версії журналу (http://www.agrisp.com) з 2014 р. розміщуються резюме, список літератури і повний текст статей англійською мовою (окрім поточного року).

Кожній статті присвоюється цифровий ідентифікатор (DOI), що сприяє коректному розповсюдженню матеріалу статті в мережі Інтернет.

Комплект документів, необхідних для ресстрації статті.

Електронною поштою надсилаються:

- лист - направлення від організації (pdf);

- договір про передачу авторських прав (pdf), оформлений та підписаний окремо кожним із співавторів, наприклад, 4 автори -

4 договори (зразок договору на сайті журналу);

- звертаємо Вашу увагу на те, що договір про передачу авторських прав набуває чинності після прийняття статті

до публікації. У разі відхилення Вашої статті редколегією журналу договір автоматично втрачає силу. Підписання договору

автором (авторами) означає, що він (вони) ознайомлений та згодний з умовами договору;

- рукопис подається doc, docx; ілюстрації; таблиці.

Статті обов'язково супроводжуються українсько-англійським словником специфічних термінів (не менше 30), використаних у статті.

Рукопис має містити:

- індекс УДК;

- назву статті англійською й українською мовами;

- прізвища та ініціали всіх авторів двома мовами;

- назву і поштову адресу(и) з індексами установ(ви), де працює(ють) автор(и), двома мовами;

- електронну пошту всіх авторів, автора для листування позначити зірочкою.

Структуровані резюме англійською та українською мовами повинні мати ідентичний зміст (кожне не менше 1500 знаків 3 пробілами). Структура резюме: Мета. Методи. Результати. Висновки. Ключові слова.

Не можна в резюме копіювати речення з розділів статті - перефразуйте їх. Резюме - це основні положення Вашої науковоі роботи. Це Ваша реклама, ї̈ прочитають тисячі науковців у різних базах даних-тому вона повинна бути зрозумілою, вичерпною, особливо пункт "методи".

«Вступ». Аналіз сучасного стану наукової проблеми, яку ви розглядаєте. До кожного факту, будь ласка, необхідно подавати кілька джерел світової літератури. В останньому абзаці вступу, крім «мети» (тільки не повторюйте заголовок рукопису), сформулюйте ідею необхідності проведення Вашого дослідження.

«Матеріали і методи». Три основних критерії: повторюваність, методи лабораторного аналізу, методи статистичної обробки (не використовуйте критерій Ст'юдента та НІР). Зміст цього розділу повинен дати можливість повністю повторити Ваші дослідження. Для багатьох експериментальних робіт цей розділ може займати «левову» частку тексту. Якщо ви працюєте з біологічними об'єктами - локальний етичний комітет повинен підтвердити програму Ваших досліджень. Про це обов'язково слід написати в розділі «Матеріали і методи» Вашого рукопису.

«Результати». Подавайте перелік основних результатів власних досліджень.

«Обговорення» - це окремий розділ Вашої роботи. Порівняння Ваших здобутків з основними дописувачами за цією темою. Тут не можна давати «нові» дані, які раніше не розглядалися в «Результатах».

«Висновки». Чи всі гіпотези даної роботи підтвердилися в світі нового, здобутого в цій роботі; перспективи подальших досліджень. Тільки не перефразовуйте розділ «Обговорення».

Дотримання етичних стандартів. Обов'язковий розділ для статей:

- вказати всі джерела фінансування роботи кожного учасника і всього колективу авторів;

- вкажіть інформацію про конфлікти інтересів;

• вкажіть інформацію про дотримання етичних стандартів при роботі, де в якості об’єктів дослідження виступають люди або тварини. 
У розділі «Підтримка» при посиланнях на гранти необхідно вказувати фонд, назву гранту та/або номер.

Таблиці повинні мати заголовок і порядковий номер. Посилання на таблиці в тексті мають відповідати порядковим номерам. Примітки до таблиць розміщують безпосередньо під ними. Всі скорочення повинні бути розшифрованими.

Ілюстрації у кольоровому або чорно-білому варіантах подавати в одному зі стандартних форматів - xls; cdr; tif; jpg; малюнки повинні бути чіткими, «живими», мати порядкові номери з прив’язкою у тексті, підписи - лаконічними та зрозумілими.

Особливу увагу просимо звернути на список цитованої літератури.

Список літератури. 32020 року журнал формує списки цитованих джерел за форматом Springer https://www.springer.com/cda/ content/document/cda_downloaddocument/Key_Style_Points_BasicRef.pdf

Нижче подаємо зразок:

За алфавітом, без нумерації:

Smith J, Jones M Jr, Houghton L et al (1999) Future of health insurance. N Engl J Med 965:325-329

Slifka MK, Whitton JL (2000) Clinical implications of dysregulated cytokine production. J Mol Med. doi:10.1007/s001090000086.

В тексті, за місцем згадування, без нумерації - (Smith J et al, 1999)

This style is based on Harvard style and recommendations of the Council of Biology Editors (CBE).

Стиль формування списку літератури див. на сайті www.agrisp.com і у журналі.

Bсі джерела повинні бути присутніми в інтернеті. DOI (при наявності) - обов’язковий елемент списку використаних джерел.

Не дозволясться «власний» переклад; назви статей з періодичних видань повинні відповідати англомовним резюме, розміщених у виданнях із зазначенням мови первинної публікації в перекладному виданні. Назви видавництв подаються у транслітерації, якщо журнал не перекладається - його назва також транслітерується.

Половина Вашої бібліографії повинна бути опублікованою за останні 5 років, не більше 5 \% бібліографії - Ваші публікації, максимум - кілька джерел «сірої літератури» (без індексів DOI).

Неприпустимо посилатися на гіперпосилання, автореферати дисертацій, монографії, матеріали з'їздів і конференцій, службові матеріали (ДСТУ).

Посилатися на інтернет-ресурси можна за наявності у джерела DOI.

Бажано цитувати джерела, опубліковані після 2010 р. (якщо це не регламентується умовами представленої роботи).

Після отримання рецензії, у випадку необхідності переробки рукопису, автор обов'язково пише пояснювального листа до рецензента і в тексті рукопису позначає кольором виправлені місця.

Увага! Статті, оформлені не за правилами, повертаються авторам без ресстрації та розгляду. 